\title{
Hypothermia for newborns with hypoxic ischemic encephalopathy
}

\author{
Abraham Peliowski-Davidovich; Canadian Paediatric Society, Fetus and Newborn \\ Committee \\ hypoxic ischemic encephalopathy. Paediatr Child Health \\ 2012;17(1):41-43.
}

\section{L'hypothermie chez les nouveau-nés présentant une encéphalopathie hypoxique-ischémique}

Hypoxic ischemic encephalopathy (HIE) remains a significant cause of mortality and long-term disability in late preterm and term infants. Mild therapeutic hypothermia to a rectal temperature of $34 \pm 0.5^{\circ} \mathrm{C}$ initiated as soon as possible within the first $6 \mathrm{~h}$ of life decreases mortality and severe long-term neurodevelopmental disabilities in infants with moderate HIE who are $\geq 36$ weeks' gestational age. There are minimal side effects, and the incidence of disability in survivors is not increased. Infants with severe encephalopathy are less likely to benefit from treatment. Cooling may be achieved by either total body or selective head cooling. As cooling is now considered a standard of care, infants $\geq 36$ weeks' gestational age who are depressed at birth should be assessed to determine whether they meet the criteria for cooling. There is currently no evidence that therapeutic hypothermia offers any benefit to infants $<36$ weeks' gestational age.

Key Words: Asphyxia, Cooling, Hypothermia, Hypoxic ischemic encephalopathy, Outcome

Despite advances in perinatal care, moderate to severe acute perinatal hypoxic ischemic encephalopathy (HIE) in late preterm and term infants remains an important cause of mortality and acute neurological injury with subsequent long-term neurodevelopmental disabilities (1). The risk of disability and impaired cognitive development correlates with the severity of $\operatorname{HIE}(1,2)$. A mild reduction in brain temperature, of $2^{\circ} \mathrm{C}$ to $4^{\circ} \mathrm{C}$, initiated within $6 \mathrm{~h}$ after birth, was the first therapy to demonstrate neuroprotection in newborn animals. Subsequently, in large randomized clinical studies, infants treated with cooling experienced significantly decreased mortality and improved neurodevelopmental outcomes (3-9). The present practice point summarizes the current evidence and issues related to the use of hypothermia for neuroprotection in neonates with HIE. The incidence of HIE is approximately $1 / 1000$ to $6 / 1000$ live births. HIE is often unanticipated, and many infants are initially cared for in community hospitals. It is important therefore, that those involved in caring for these infants - family physicians, community paediatricians and neonatologists - recognize when cooling may be beneficial.

Impaired cerebral blood flow, in the setting of hypoxia, is the main mechanism causing brain injury following intrapartum hypoxia-ischemia $(1,2,10)$. At the cellular level, hypoxia-ischemia results in two phases of energy failure. The primary phase follows the reduction in blood flow and oxygen supply with a fall in ATP, failure of the $\mathrm{Na}+/ \mathrm{K}+$ pump, depolarization of cells, lactic acidosis, release of excitatory amino acids, calcium entry into the cell and, if severe, cell necrosis $(1,2,10)$. Following resuscitation and reperfusion, there is a latent period with normalization of oxidative metabolism lasting
L'encéphalopathie hypoxique-ischémique (EHI) demeure une cause importante de mortalité et d'invalidité à long terme chez les nourrissons peu prématurés et à terme. L'hypothermie thérapeutique bénigne à une température rectale de $34^{\circ} \mathrm{C} \pm 0,5^{\circ} \mathrm{C}$ amorcée le plus rapidement possible dans les six premières heures de vie réduit la mortalité et les graves invalidités neurodéveloppementales à long terme chez les nourrissons d'au moins 36 semaines d'âge gestationnel ayant une EHI modérée. Les effets secondaires sont minimes, et l'incidence d'incapacité chez les survivants n'est pas plus élevée. Les nourrissons ayant une grave encéphalopathie sont moins susceptibles de profiter du traitement. On peut opter pour le refroidissement du corps entier ou de la tête seulement. Puisque le refroidissement est désormais considéré comme une norme de soins, les nourrissons d'au moins 36 semaines d'âge gestationnel qui sont en détresse neurologique à la naissance devraient faire l'objet d'une évaluation afin de déterminer s'ils respectent les critères de refroidissement. Pour l'instant, il n'existe aucunes données probantes indiquant que l'hypothermie thérapeutique apporte des bienfaits aux nourrissons de moins de 36 semaines d'âge gestationnel.

$6 \mathrm{~h}$ to $12 \mathrm{~h}$, which is the therapeutic window for neuroprotective interventions. The secondary phase of energy failure develops at $12 \mathrm{~h}$ to $36 \mathrm{~h}$, and may last seven to 14 days with initiation of apoptosis, mitochondrial failure, cytotoxic edema, accumulation of excitatory amino acids and release of free radicals terminating in cell death $(1,2,10)$. This secondary phase is associated with worsening of HIE and correlates with poor outcomes $(1,2)$.

Therapeutic mild hypothermia's mechanism of protection is multifactorial and is attributed to a broad inhibitory activity against a variety of harmful cell processes. The beneficial effects of mild hypothermia include amelioration of apoptosis, decreased loss of high-energy phosphates, reduced oxygen consumption, reduced release of nitric oxide, glutamate, free radicals and excitatory amino acid neurotransmitters, and the induction of genes that reduce neuronal death $(1,3,4)$.

Brain hypothermia can be achieved safely using either selective head cooling with mild systemic hypothermia (temperature $34^{\circ} \mathrm{C}$ to $\left.35^{\circ} \mathrm{C}\right)(6,8)$ or total body cooling $(7,9)$. The Cochrane review of cooling for newborns with moderate and severe HIE analyzed eight trials that utilized both methods of cooling and concluded that hypothermia reduced the combined outcome of mortality or major neurodevelopmental disability at 18 months (RR $0.76 ; 95 \%$ CI 0.65 to 0.89 ), reduced mortality (RR 0.74; $95 \%$ CI 0.58 to 0.94$)$ and reduced neurodevelopmental disability in survivors (RR 0.68; 95\% CI 0.51 to 0.92) (3). Two recent trials not included in the Cochrane review also reported beneficial effects of cooling; decreased severe disability and death in one study (8) and improved neurological outcomes in the other study 
TABLE 1

Clinical criteria for hypoxic ischemic encephalopathy (HIE)

\begin{tabular}{|c|c|c|c|}
\hline \multirow[b]{2}{*}{ Category } & \multicolumn{3}{|c|}{ HIE } \\
\hline & Mild & Moderate & Severe \\
\hline Level of consciousness & Hyperalert & Lethargic & $\begin{array}{c}\text { Stupor or } \\
\text { coma }\end{array}$ \\
\hline Spontaneous activity & Normal & Decreased & No activity \\
\hline \multicolumn{4}{|l|}{ Neuromuscular control } \\
\hline Tone & Normal & Mild hypotonia & Flaccid \\
\hline Posture & $\begin{array}{l}\text { Mild distal } \\
\text { flexion }\end{array}$ & $\begin{array}{l}\text { Strong distal } \\
\text { flexion }\end{array}$ & Decerebrate \\
\hline Stretch reflexes & Overactive & Overactive & Absent \\
\hline Segmental myoclonus & Present & Present & Absent \\
\hline \multicolumn{4}{|l|}{ Primary reflexes } \\
\hline Suck & Weak & Weak or absent & Absent \\
\hline Moro & Strong & Weak & Absent \\
\hline Oculovestibular & Normal & Overactive & Absent \\
\hline Autonomic system & Sympathetic & Parasympathetic & Both absent \\
\hline Pupils & Mydriasis & Miosis & Nonreactive \\
\hline Heart rate & Tachycardia & Bradycardia & Variable \\
\hline Respiration & Normal & Periodic & Apnea \\
\hline Secretions & Sparse & Profuse & Variable \\
\hline Seizures & None & Common & Uncommon \\
\hline Electroencephalogram & $\begin{array}{l}\text { Mild } \\
\text { depression }\end{array}$ & $\begin{array}{l}\text { Moderate } \\
\text { depression }\end{array}$ & $\begin{array}{l}\text { Severe } \\
\text { depression }\end{array}$ \\
\hline
\end{tabular}

Modified from reference 14

(9). Treatment with either head cooling or total body cooling has been shown to decrease both death and disability in infants with moderate HIE, but has less certain therapeutic impact in infants with severe HIE $(3,8,9)$.

\section{SHOULD HYPOTHERMIA BE ROUTINELY OFFERED TO INFANTS WITH HIE?}

Hypothermia is the only available effective neuroprotective treatment for HIE, and is now considered the standard of care for infants with moderate to severe HIE (11-13). A concern remains that hypothermia may be less beneficial for infants with severe encephalopathy, and that its use may delay end-of-life decisionmaking for infants with an extremely poor prognosis.

\section{WHICH INFANTS SHOULD BE TREATED WITH HYPOTHERMIA?}

Current evidence shows that the infants who benefit from hypothermia are term and late preterm infants $\geq 36$ weeks' gestation with HIE who are $\leq 6 \mathrm{~h}$ of age and who meet both treatment criteria A and B:

\section{Criteria A}

Any two of the following:

- Apgar score $<5$ at 10 min of age.

- Continued need for ventilation and resuscitation at $10 \mathrm{~min}$ of age.

- Metabolic acidosis with $\mathrm{pH}<7$ or base deficit $>16 \mathrm{mmol} / \mathrm{L}$ in cord or arterial blood gases measured within $1 \mathrm{~h}$ of birth. AND

\section{Criteria B}

- Moderate (Sarnat stage II) or severe (Sarnat stage III) encephalopathy demonstrated by the presence of seizures or at least one sign in at least three of the six categories shown in Table 1 (14).

All infants who are depressed at birth should be assessed to determine whether they fulfill criteria A. Infants who fulfill criteria A should then undergo a careful neurological examination to determine whether they fulfill criteria B. Infants who meet both criteria should be offered hypothermia. If possible, it is helpful to assess infants with an amplitude-integrated electroencephalogram for at least $20 \mathrm{~min}$ before $5.5 \mathrm{~h}$ of age to document abnormal tracings or seizures (15).

\section{WHERE SHOULD HYPOTHERMIA BE PROVIDED?}

Hypothermia should be provided in level III neonatal intensive care units where resources are available to treat multiorgan failure that may be associated with HIE, as well as possible complications of the hypothermia treatment such as cardiac arrhythmias and bleeding diathesis. Centres providing hypothermia should have access to ultrasound, computed tomography and magnetic resonance neuroimaging, as well as be able to perform electroencephalograms (EEGs) and neurosensory evoked potential recordings.

Early cooling, before $6 \mathrm{~h}$ of age by trained physicians in community hospitals may be beneficial and should only be initiated following consultation with a level III neonatal intensive care unit. Mild hypothermia can be achieved passively by turning off the overhead warmer, or with ice or cool gel packs while awaiting transport and can be continued during transport. Careful control of body temperature is important.

\section{WHICH INFANTS SHOULD NOT BE ROUTINELY COOLED?}

Evidence of severe head trauma or intracranial bleeding is a contraindication to cooling. There are currently no published studies showing that cooling infants $>6$ h of age or $<36$ weeks' gestational age is beneficial. Initiation of cooling for infants with very severe encephalopathy, congenital anomalies or abnormal chromosomes is best performed in consultation with a tertiary centre.

\section{WHICH METHOD OF COOLING SHOULD BE USED?}

Clinical trials have found similar effects, using either selective head cooling with mild systemic hypothermia or total body cooling, on death and disability; however, there are no randomized trials comparing head and body cooling. Selective head cooling with mild systemic hypothermia can be achieved with cooling caps fitted around the infant's head, with the aim of maintaining fontanelle temperature below $30^{\circ} \mathrm{C}$. A rectal temperature of $34 \pm 0.5^{\circ} \mathrm{C}$ is maintained with a servo-controlled radiant heater. This system is expensive and labour intensive, and can produce scalp edema or skin breakdown. It is also more difficult to maintain rectal temperature and there is limited access for EEGs. Total body cooling to a rectal temperature of $34 \pm 0.5^{\circ} \mathrm{C}$ can be achieved with passive cooling, cool packs and/or commercially available cooling blankets. Total body cooling is easier to use, less expensive, provides access to EEGs and is more likely be available in the hospital. A recent survey reported a $65 \%$ use of body cooling, $25 \%$ of selective head cooling and use of both in $10 \%$ of the centres surveyed (16).

What is the target temperature to be reached?

The range of rectal or esophageal temperature in the trials varied between $32.5^{\circ} \mathrm{C}$ to $35^{\circ} \mathrm{C}$ using either method of cooling. The optimal rectal or esophageal temperature appears to be $34 \pm 0.5^{\circ} \mathrm{C}(3)$.

How long should the cooling last?

The optimal duration of treatment is unknown. The duration of hypothermia in trials lasted between $48 \mathrm{~h}$ to $72 \mathrm{~h}$. Most used $72 \mathrm{~h}$ of cooling. 
How should the infant be rewarmed?

The speed of rewarming is controversial and varies between increasing rectal temperatures by $0.5^{\circ} \mathrm{C}$ every hour to every $4 \mathrm{~h}$. The consensus is that rewarming should be slow. Most centres rewarm infants by $0.5^{\circ} \mathrm{C}$ every $2 \mathrm{~h}$. Worsening of encephalopathy and seizures on rewarming has been reported, in which case infants may require recooling (17).

\section{Is hypothermia safe?}

Mild hypothermia is safe with no serious side effects reported $(3,12)$. Mild bradycardia, mild hypotension, arrythmias, mild thrombocytopenia and sclerema/edema have been described $(3,12)$.

\section{CAN COOLING BE USED IN PREMATURE INFANTS?}

Hypothermia is associated with increased mortality in the premature infant (18). Data in premature and fetal asphyxiated animals are controversial, with some studies showing no effect and others showing improvement (19). There is currently no evidence that therapeutic hypothermia offers any benefit to infants $<36$ weeks' gestational age; the safety and efficacy of cooling in this population are unknown. Clinical trials in late preterm infants are in progress (20).

\section{WHAT ABOUT FOLLOW-UP OF COOLED INFANTS?}

Follow-up at 18 to 24 months has been the standard of care in hypothermia trials. Minimal data exist on longer-term neurodevelopmental outcomes of treated infants. Multidisciplinary follow-up to assess long-term motor, psychoeducational, auditory and cognitive outcomes is an important part of care for cooled infants.

\section{CONCLUSION}

Mild therapeutic hypothermia to a temperature of $34 \pm 0.5^{\circ} \mathrm{C}$ initiated as soon as possible within the first $6 \mathrm{~h}$ of life decreases mortality and severe long-term neurodevelopmental disabilities in infants with moderate HIE, with minimal side effects and without increasing the incidence of disability in survivors. It should only be initiated in level III units or in consultation with a level III neonatologist before transport. Long-term neurodevelopmental outcomes in these infants with moderate encephalopathy is unknown. Infants with severe encephalopathy are less likely to benefit from treatment. There are no differences in outcomes between total body and selective head cooling.

Hypothermia is safe and has become the standard of care for neonatal HIE.

ACKNOWLEDGEMENTS: This practice point was reviewed by the Canadian Paediatric Society's Community Paediatrics Committee.

\section{REFERENCES}

1. Ferriero DM. Neonatal brain injury. N Engl J Med 2004;351:1985-95.

2. Shalak L, Perlman JM. Hypoxic-ischemic brain injury in the term infant - current concepts. Early Hum Dev 2004;80:125-41.

3. Jacobs S, Hunt R, Tarnow-Mordi W, Inder T, Davis P. Cooling for newborns with hypoxic ischemic encephalopathy. Cochrane Database Syst Rev 2007;(4):CD003311.

4. Wilkinson DJ, Casalaz D, Watkins A, Andersen CC, Duke T. Hypothermia: A neuroprotective therapy for neonatal hypoxicischemic encephalopathy. Pediatrics 2007;119:422-3.

5. Shah PS, Ohlsson A, Perlman M. Hypothermia to treat neonatal hypoxic ischemic encephalopathy: Systematic review. Arch Pediatr Adolesc Med 2007;161:951-8.

6. Gluckman PD, Wyatt JS, Azzopardi D, et al. Selective head cooling with mild systemic hypothermia after neonatal encephalopathy: Multicentre randomised trail. Lancet 2005;365:663-70.

7. Shankaran S, Laptook AR, Ehrenkranz RA, et al. Whole-body hypothermia for neonates with hypoxic-ischemic encephalopathy. N Engl J Med 2005;353:1574-84.

8. Zhou WH, Cheng GQ, Shao XM, et al. Selective head cooling with mild systemic hypothermia after neonatal hypoxic-ischemic encephalopathy: A multicenter randomized controlled trial in China. J Pediatr 2010;157:367-72.

9. Azzopardi DV, Strohm B, Edwards AD, et al. Moderate hyopthermia to treat perinatal asphyxial encephalopathy. N Engl J Med 2009;361:1349-58.

10. Gunn AJ, Bennet L. Fetal hypoxia insults and patterns of brain injury: Insight from animal models. Clin Perinatol 2009;36:579-93.

11. Gunn AJ, Hoehn T, Hansmann G, et al. Hypothermia: An evolving treatment for neonatal hypoxic ischemic encephalopathy. Pediatrics 2008;121:648-9.

12. Blackmon LR, Stark AR; American Academy of Pediatrics Committee on Fetus and Newborn. Hypothermia: A neuroprotective therapy for neonatal hypoxic-ischemic encephalopathy. Pediatrics 2006;117:942-8.

13. Higgins RD, Raju TN, Perlman J, et al. Hypothermia and perinatal asphyxia: Executive summary of the National Institute of Child Health and Human Development workshop. J Pediatr 2006;148:170-5.

14. Sarnat HB, Sarnat MS. Neonatal encephalopathy following fetal distress. A clinical and electroencephalographic study. Arch Neurol 1976;33:696-705.

15. Hellström-Westas L, Rosén I. Amplitude-integrated electroencephalogram in newborn infants for clinical and research purposes. Acta Paediatr 2002;91:1028-30.

16. Lang TR, Hartman TK, Hintz SR, Colby CE. Hypothermia for the treatment of neonatal ischemic encephalopathy: Is the genie out of the bottle? Am J Perinatol 2007;24:27-31.

17. Battin M, Bennet L, Gunn AJ. Rebound seizures during rewarming. Paediatrics 2004;114:1369.

18. Costeloe K, Hennessy E, Gibson AT, Marlow N, Wilkinson AR. The EPICure study: Outcomes to discharge from hospital for infants born at the threshold of viability. Pediatrics 2000;106:659-71.

19. Bennet L, Roelfsema V, George S, Dean JM, Emerald BS, Gunn AJ. The effect of cerebral hypothermia on white and grey matter injury induced by severe hypoxia in preterm fetal sheep. J Physiol 2007;578:491-506

20. Gunn AJ, Bennet L. Brain cooling for preterm infants. Clin Perinatol 2008;35:735-48.

\section{FETUS AND NEWBORN COMMITTEE}

Members: Ann L Jefferies MD (Chair); Thierry Lacaze-Masmonteil MD; Abraham Peliowski-Davidovich MD; S Todd Sorokan MD; Richard Stanwick MD (Board Representative); Hilary EA Whyte MD

Liaisons: Michael S Dunn MD, CPS Neonatal-Perinatal Medicine Section; Sandra Dunn MScN, Canadian Perinatal Programs Coalition; Andrée Gagnon MD, College of Family Physicians of Canada; Robert Gagnon MD, Society of Obstetricians and Gynaecologists of Canada; Juan Andrés León MD, Public Health Agency of Canada; Patricia O'Flaherty MN MEd, Canadian Association of Neonatal Nurses; Lu-Ann Papile MD, American Academy of Pediatrics, Committee on Fetus and Newborn

Consultant: Robin K Whyte MD

Principal author: Abraham Peliowski-Davidovich MD

The recommendations in this document do not indicate an exclusive course of treatment or procedure to be followed. Variations, taking into account individual circumstances, may be appropriate. All Canadian Paediatric Society position statements and practice points are reviewed on a regular basis. Please consult the Position Statements section of the CPS website (www.cps.ca) for the full-text, current version. 